\title{
Occupational Anxiety of Prospective Physical Education and Sports Teachers in Turkey
}

\section{Zeki Coşkuner ${ }^{1}$ \\ Fatih Mehmet Ŭgurlu²}

${ }^{2}$ Ph.D., Firat University, Faculty of Sports Sciences, Turkey.

'Email: coskuner:eki@gmail.com Tel: +905053878568

'Email:fmugurlu@firat.edu.tr.Tel: +905356207177

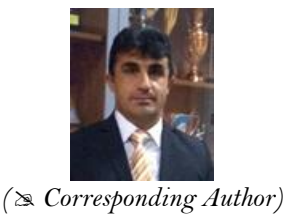

\section{Abstract}

This study was conducted to reveal the occupational anxiety levels of prospective physical education and sports teachers in Turkey. The sample of the study consisted of 354 prospective teachers who were chosen by the random sampling method from four universities. The "Occupational Anxiety Scale" was used to collect the data from the sample group in the study. The "Independent Samples t-test", which is one of the parametric tests, was conducted to reveal the differences according to the gender variable while another parametric test, the "One-way Variance Analysis". Furthermore, the "Pearson Correlation Analysis" was conducted to determine the nature and the level of correlation between dependent variables. In the study, statistically significant differences were observed between the groups in the subscale of "occupational exam" according to the gender variable. According to the variable of the grade level, significant differences were observed between the groups in the subscale of "adaptation". As a result of the correlation analysis, it was observed that the subscales of "occupation" and "job orientation" were positively and very strongly correlated, which was also the strongest correlation in the analysis. On the other hand, the weakest correlation was determined to be between the subscales of "occupational exam" and "colleagues and parents", which was a positive and weak correlation $(\mathrm{p}<0.05)$. It was discovered that the occupational anxiety of prospective teachers was generally based on the occupational exam and adaptation.

Keywords: Sport, Anxiety, Occupational anxiety, Prospective, Physical education, Sports teacher, Anxiety scale.

Citation | Zeki Coşuner; Fatih Mehmet Uğurlu (2020). Occupational Anxiety of Prospective Physical Education and Sports Teachers in Turkey. Asian Journal of Education and Training, 6(3): 520-526.

History:

Received: 25 May 2020

Revised: 30 June 2020

Accepted: 19 August 9020

Accepted: 19 August 2020

Licensed: This work is licensed under a Creative Commons

Licensed: This work is

Publisher: Asian Online Journal Publishing Group
Acknowledgement: Both authors contributed to the conception and design of the study.

Funding: This study received no specific financial support.

Competing Interests: The authors declare that they have no conflict of interests.

Transparency: The authors confirm that the manuscript is an honest, accurate, and transparent account of the study was reported; that no vital features of the study have been omitted; and that any discrepancies from the study as planned have been explained.

Ethical: This study follows all ethical practices during writing.

\section{Contents}

1. Introduction 


\section{Contribution of this paper to the literature}

This study was conducted to reveal the occupational anxiety levels of prospective physical education and sports teachers in Turkey.

\section{Introduction}

Education systems cover three intertwined elements (students, teachers, and education programs) and teachers are the most important element of education systems among these three elements (Atmaca, 2013; Donmuş, Akpunar, \& Eroğlu, 2017; Mergen, Arslan, Mergen, \& Arslan, 2014).

The profession of teaching, which facilitates the transfer of universal and local cultural heritage to new generations, the emergence of individuals' skills, and gaining new knowledge and skills, has a distinct place from other professions in every society. To practice a profession with such significance, teachers are required to possess characteristics such as patients, devotion, and intentness (Capa \& Cil, 2000; Güven, 2010).

Although anxiety, which significantly influences an individual's performance, is defined as a negative emotion that results in worry and sadness, it is also defined as a part of life and emotion that enables resilience against difficulties. Today, many factors stimulate the anxiety levels of prospective teachers. Some of these include "making a positive impression on people around them, establishing sufficient communication with students, achieving professional satisfaction, and economic conditions". Additionally, prospective teachers who complete their education prepare for their exams under ever more difficult conditions where the preparation phase paves the way for psychological problems such as anxiety, worry, and fear (Celik, 2017). When the literature was reviewed, three subjects, "selfcentered, job-centered, and student-centered anxiety”, were observed to be the sources of anxiety experienced by prospective teachers. Self-centered anxiety refers to an individual's self. A prospective teacher with such a type of anxiety covers whether the profession is practiced successfully and this constantly results in extreme stress in prospective teachers. The subject of job-centered anxiety covers the teaching duty of individuals. Prospective teachers with such a type of anxiety worry about becoming a decent teacher. Thus, they look for novel information, method, and material to be used in their occupation. The focus of the student-based anxiety is students. Prospective teachers with such a type of anxiety worry about students. In other words, they worry about how to meet the social, emotional, and mental requirements of students in the best way possible and conduct research on this subject (Fuller, 1996; Taşğın, 2006).

Numerous studies investigated the concept of self-efficacy in prospective teachers in detail while it was observed that the number of studies conducted on the concept of occupational anxiety in prospective teachers was limited (Atmaca, 2013; Dadandı, Kalyon, \& Yazıcı, 2016; Mishra \& Yadav, 2013; Singh, 2011). Accordingly, it is believed that studies conducted on the concept of occupational anxiety, which is cited as a significant factor that affects their professional career, in prospective teachers during the pre-service period (Allinder, 1994; Atmaca, 2013; Cousins \& Walker, 2000; Singh, 2011; Tektaş, 2014) will contribute to increasing the quality of education.

In Turkey, the value of the profession of teaching in the society's eyes has been decreasing gradually and the complaints and uneasiness of teachers toward working and living conditions have been growing, which is reflected as lesser interest for this profession in future generations and decreases in the order of choice to last ranks. Such negative developments also result in certain anxieties in prospective and in-service physical education and sports teachers. This profession, which is practiced by overcoming various problems pre-service and in-service problems by physical education and sports teachers, has a structure that requires individuals to develop and update themselves during their educational and professional lives. At this point, the prospective physical education teachers' education and their will to develop themselves have vital importance. The prospective physical education and sports teachers, who will shape future generations, may lose their will to achieve academic success, become professionally equipped, and to develop themselves when they worry about their futures.

Prospective physical education and sports teachers receive both theoretical and practical lessons with content knowledge during their undergraduate education. However, these lessons focus on the education process rather than individual differences and emotional states of prospective teachers. Accordingly, this study aimed to reveal occupational anxiety in prospective physical education and sports teachers in Turkey. Therefore, it is of importance to investigate their occupational anxiety of prospective physical education and sports teachers, which is believed to hinder their future performance, as well as ensuring that they complete their educational process with the required knowledge and skills. Determining these anxieties and devising possible solutions for them will enable prospective physical education and sports teachers to become more efficient in their profession. It is also believed that determining the occupational anxiety of prospective physical education and sports teachers before stepping into professional life will contribute to studies on teachers and teacher training.

\section{Material and Method}

In this study, the "quantitative method" was used with the relational survey research design. The sample of the study consisted of 354 prospective physical education and sports education, who studied in the Faculties of Sports Sciences at Fırat University (163 prospective teachers), Nevşehir University (88 prospective teachers), Harran University (55 prospective teachers) and İnönü University (48 prospective teachers) in Turkey. The "Occupational Anxiety Scale”, which was developed by Cabi and Yalçınalp (2013) was used to collect the data from the participants. During the development of the scale, Cabi and Yalçınalp (2013) conducted their study with 283 prospective teachers who studied in various departments in Faculties of Education. For the validity and reliability of the "Occupational Anxiety Scale", content validity, construct validity, adjusted item-total correlation, Cronbach alpha coefficient, and split-half test correlations were investigated. As a result of these analyses, the scale was finalized with 45 items and 8 subscales. The subscales of the "Occupational Anxiety Scale" covered "Job orientation (14 items)", "Socioeconomics (7 items)", "Interaction with Students (6 items)", "Colleagues and Parents (5 items)", "Personal Development (4 items)", "Occupational Exam (3 items)", "Adaptation (3 items)", and "School Management (3 items)".

The data obtained from 354 prospective teachers were first analyzed in terms of normal distribution in the Occupational Anxiety Scale and its subscales Table 1. The skewness and kurtosis values of the Occupational 
Anxiety Scale and its subscales were observed to be between +1.5 and -1.5 . Tabachnick, Fidell, and Ullman (2007) stated that skewness and kurtosis values between +1.5 and -1.5 could indicate the presence of normal distribution. Accordingly, it was concluded that the data in the study exhibited a normal distribution.

Table-1. Results of normality tests of the occupational anxiety scale and its subscales

\begin{tabular}{l|c|c|c|c|c}
\hline Scale & $\mathbf{N}$ & Mean & Standard Deviation & Skewness & Kurtosis \\
\hline Occupational Anxiety Scale & 354 & 2.443 & 0.856 & {$[0.274 ; 0.130]$} & {$[-0.769 ; 0.259]$} \\
\hline Job Orientation & 354 & 2.309 & 0.970 & {$[0.381 ; 0.130]$} & {$[-0.880 ; 0.259]$} \\
\hline Socioeconomics & 354 & 2.502 & 0.935 & {$[0.130 ; 0.130]$} & {$[-0.778 ; 0.259]$} \\
\hline Interaction with Students & 354 & 2.362 & 1.037 & {$[0.312 ; 0.130]$} & {$[-0.882 ; 0.259]$} \\
\hline Colleagues and Parents & 354 & 2.366 & 1.023 & {$[0.295 ; 0.130]$} & {$[-0.895 ; 0.259]$} \\
\hline Personal Development & 354 & 2.435 & 1.100 & {$[0.308 ; 0.130]$} & {$[-0.817 ; 0.259]$} \\
\hline Occupational Exam & 354 & 3.036 & 1.099 & {$[-0.077 ; 0.130]$} & {$[-0.584 ; 0.259]$} \\
\hline Adaptation & 354 & 2.467 & 1.052 & {$[0.267 ; 0.130]$} & {$[-0.721 ; 0.259]$} \\
\hline School Management & 354 & 2.609 & 1.018 & {$[0.118 ; 0.130]$} & {$[-0.784 ; 0.259]$} \\
\hline Note: ${ }^{*}$ p $<0.05$. & &
\end{tabular}

Then, a parametric test, the "Independent Samples t-test", was conducted to evaluate the level of differentiation in terms of the variable of gender, which is an independent variable while "One-way Variance Analysis", which is a parametric test, was conducted to evaluate the differentiation in terms of the variable of grade level. In the study, the level of statistical significance ( $\alpha$ error level) was regarded as $\mathrm{p}<0.05$. The "Pearson Correlation Analysis" was conducted to determine the nature and level of correlation between dependent variables. The level of correlations between dependent variables were evaluated according to Kalaycı (2006) (0.00-0.25 = Very Weak Correlation; 0.26-0.49 = Weak Correlation; 0.50-0.69 = Moderate Correlation; 0.70-0.89 = Strong Correlation; 0.90-1.00 = Very Strong Correlation).

\section{Findings}

In parallel with the aims of the study, the results obtained from the perceptions of prospective physical education and sports teachers were presented below.

Table-2. Results of independent samples t-test conducted to reveal whether there were differences in the sample group according to the variable of gender.

\begin{tabular}{|c|c|c|c|c|c|c|}
\hline Scale & Gender & $\mathbf{N}$ & $\overline{\mathbf{x}}$ & SD & t-Value & p-Value \\
\hline \multirow[t]{2}{*}{ Job Orientation } & Male & 238 & 2.343 & 0.986 & \multirow{2}{*}{0.925} & \multirow{2}{*}{0.356} \\
\hline & Female & 116 & 2.241 & 0.938 & & \\
\hline \multirow[t]{2}{*}{ Socioeconomics } & Male & 238 & 2.536 & 0.924 & \multirow{2}{*}{0.974} & \multirow{2}{*}{0.331} \\
\hline & Female & 116 & 2.433 & 0.957 & & \\
\hline \multirow[t]{2}{*}{ Interaction with Students } & Male & 238 & 2.329 & 1.039 & \multirow{2}{*}{-0.867} & \multirow{2}{*}{0.387} \\
\hline & Female & 116 & 2.431 & 1.035 & & \\
\hline \multirow[t]{2}{*}{ Colleagues and Parents } & Male & 238 & 2.348 & 1.009 & \multirow{2}{*}{-0.457} & \multirow{2}{*}{0.648} \\
\hline & Female & 116 & 2.401 & 1.053 & & \\
\hline \multirow[t]{2}{*}{ Personal Development } & Male & 238 & 2.445 & 1.074 & \multirow{2}{*}{0.253} & \multirow{2}{*}{0.800} \\
\hline & Female & 116 & 2.413 & 1.156 & & \\
\hline \multirow[t]{2}{*}{ Occupational Exam } & Male & 238 & 2.941 & 1.071 & \multirow{2}{*}{-2.358} & \multirow{2}{*}{$0.019 *$} \\
\hline & Female & 116 & 3.232 & 1.132 & & \\
\hline \multirow[t]{2}{*}{ Adaptation } & Male & 238 & 2.508 & 1.051 & \multirow{2}{*}{1.059} & \multirow{2}{*}{0.290} \\
\hline & Female & 116 & 2.382 & 1.054 & & \\
\hline \multirow[t]{2}{*}{ School Management } & Male & 238 & 2.599 & 0.994 & \multirow{2}{*}{-0.259} & \multirow{2}{*}{0.796} \\
\hline & Female & 116 & 2.629 & 1.071 & & \\
\hline
\end{tabular}

Note: ${ }^{*} \mathrm{p}<0.05$

T-test analysis was conducted to reveal whether there were statistically significant differences in the sample group

According to the variable of gender Table 2. As a result, it was observed that there were statistically significant differences in the subscale of the "Occupational Exam" ( $p<0.05)$. In terms of other subscales, no significant difference was observed ( $\mathrm{p}>0.05)$.

The one-way variance analysis was conducted to determine whether there were differences in the sample group according to the variable of grade level Table 3 . As a result, it was observed that there were statistically significant differences in the subscale of "Adaptation" $(\mathrm{p}<0.05)$. No statistically significant difference was observed in other subscales $(\mathrm{p}>0.05)$.

In parallel with the perceptions of the sample group, correlation analyses were conducted Table 4. As a result, it was observed that the "Occupational Anxiety Scale" and the subscale of "Job Orientation" were positively very strongly correlated. Furthermore, it was determined that the weakest correlation was between the subscales of "Occupational Exam" and "Colleagues and Parents", which was positive and very weak ( $<<0.05)$.

\section{Discussion and Conclusion}

In parallel with the aims of the study, the results obtained from the perceptions of the prospective physical education and sports teachers were discussed and presented. 
Table-3. Results of one-way variance analysis (ANOVA) conducted to reveal whether there were differences in the sample group according to the variable of grade level.

\begin{tabular}{|c|c|c|c|c|c|c|c|}
\hline Scale & Grade Level & $\mathbf{N}$ & $\bar{x}$ & SD & $\mathbf{F}$ & p-Value & LSD \\
\hline \multirow{4}{*}{ Job Orientation } & (a) $1^{\text {st }}$ Grade & 47 & 2.308 & 0.924 & \multirow{4}{*}{0.947} & \multirow{4}{*}{0.418} & \\
\hline & (b) $2^{\text {nd }}$ Grade & 87 & 2.351 & 0.929 & & & \\
\hline & (c) $3^{\text {rd }}$ Grade & 133 & 2.379 & 0.997 & & & \\
\hline & (d) $4^{\text {th }}$ Grade & 87 & 2.162 & 0.993 & & & \\
\hline \multirow{4}{*}{ Socioeconomics } & (a) $1^{\text {st }}$ Grade & 47 & 2.595 & 0.798 & \multirow{4}{*}{1.307} & \multirow{4}{*}{0.272} & \\
\hline & (b) $2^{\text {nd }}$ Grade & 87 & 2.610 & 0.903 & & & \\
\hline & (c) $3^{\text {rd }}$ Grade & 133 & 2.498 & 0.972 & & & \\
\hline & (d) $4^{\text {th }}$ Grade & 87 & 2.351 & 0.969 & & & \\
\hline \multirow{4}{*}{ Interaction with Students } & (a) $1^{\text {st }}$ Grade & 47 & 2.365 & 1.103 & \multirow{4}{*}{0.418} & \multirow{4}{*}{0.740} & \\
\hline & (b) $2^{\text {nd }}$ Grade & 87 & 2.375 & 0.958 & & & \\
\hline & (c) $3^{\text {rd }}$ Grade & 133 & 2.419 & 1.043 & & & \\
\hline & (d) $4^{\text {th }}$ Grade & 87 & 2.260 & 1.077 & & & \\
\hline \multirow{4}{*}{ Colleagues and Parents } & (a) $1^{\text {st }}$ Grade & 47 & 2.374 & 0.983 & \multirow{4}{*}{1.894} & \multirow{4}{*}{0.130} & \\
\hline & (b) $2^{\text {nd }}$ Grade & 87 & 2.542 & 0.974 & & & \\
\hline & (c) $3^{\text {rd }}$ Grade & 133 & 2.372 & 1.044 & & & \\
\hline & (d) $4^{\text {th }}$ Grade & 87 & 2.174 & 1.042 & & & \\
\hline \multirow{4}{*}{ Personal Development } & (a) $1^{\text {st }}$ Grade & 47 & 2.537 & 1.149 & \multirow{4}{*}{1.220} & \multirow{4}{*}{0.302} & \\
\hline & (b) $2^{\text {nd }}$ Grade & 87 & 2.583 & 1.060 & & & \\
\hline & (c) $3^{\text {rd }}$ Grade & 133 & 2.396 & 1.057 & & & \\
\hline & (d) $4^{\text {th }}$ Grade & 87 & 2.290 & 1.171 & & & \\
\hline \multirow{4}{*}{ Occupational Exam } & (a) $1^{\text {st }}$ Grade & 47 & 2.893 & 1.002 & \multirow{4}{*}{0.522} & \multirow{4}{*}{0.667} & \\
\hline & (b) $2^{\text {nd }}$ Grade & 87 & 2.996 & 1.110 & & & \\
\hline & (c) $3^{\text {rd }}$ Grade & 133 & 3.052 & 1.137 & & & \\
\hline & (d) $4^{\text {th }}$ Grade & 87 & 3.130 & 1.085 & & & \\
\hline \multirow{4}{*}{ Adaptation } & (a) $1^{\text {st }}$ Grade & 47 & 2.461 & 0.941 & \multirow{4}{*}{3.641} & \multirow{4}{*}{$0.013^{*}$} & \multirow{4}{*}{$b, d$} \\
\hline & (b) $2^{\text {nd }}$ Grade & 87 & 2.735 & 1.046 & & & \\
\hline & (c) $3^{\text {rd }}$ Grade & 133 & 2.458 & 1.099 & & & \\
\hline & (d) $4^{\text {th }}$ Grade & 87 & 2.214 & 0.992 & & & \\
\hline \multirow{4}{*}{ School Management } & (a) $1^{\text {st }}$ Grade & 47 & 2.666 & 0.911 & \multirow{4}{*}{0.336} & \multirow{4}{*}{0.799} & \\
\hline & (b) $2^{\text {nd }}$ Grade & 87 & 2.670 & 1.021 & & & \\
\hline & (c) $3^{\text {rd }}$ Grade & 133 & 2.601 & 1.054 & & & \\
\hline & (d) $4^{\text {th }}$ Grade & 87 & 2.528 & 1.027 & & & \\
\hline
\end{tabular}

Table-4. Results of correlation analysis conducted to reveal the correlations between the occupational anxiety scale and its subscales.

\begin{tabular}{|c|c|c|c|c|c|c|c|c|c|c|}
\hline \multirow{2}{*}{$\begin{array}{l}\text { Occupational } \\
\text { Anxiety Scale } \\
\text { (1) }\end{array}$} & $\mathbf{r}$ & 1 & & & & & & & & \\
\hline & $\mathbf{N}$ & 354 & & & & & & & & \\
\hline $\begin{array}{l}\text { Job Orientation } \\
(2)\end{array}$ & $\mathbf{r}$ & $0.948^{*}$ & 1 & & & & & & & \\
\hline \multirow{3}{*}{$\begin{array}{l}\text { Socioeconomics } \\
\text { (3) }\end{array}$} & $\mathbf{r}$ & $0.873^{*}$ & $0.745^{*}$ & 1 & & & & & & \\
\hline & $p$ & 0.000 & 0.000 & - & & & & & & \\
\hline & $\mathbf{N}$ & 354 & 354 & 354 & & & & & & \\
\hline \multirow{2}{*}{$\begin{array}{l}\text { Interaction with } \\
\text { Students (4) }\end{array}$} & $\mathbf{r}$ & 0.868* & $0.859^{*}$ & $0.648^{*}$ & 1 & & & & & \\
\hline & p & 0.000 & 0.000 & 0.000 & - & & & & & \\
\hline $\begin{array}{l}\text { Colleagues and } \\
\text { Parents (5) }\end{array}$ & $\mathbf{N}$ & 354 & 354 & 354 & 354 & 354 & & & & \\
\hline \multirow{3}{*}{$\begin{array}{l}\text { Personal } \\
\text { Development } \\
(6) \\
\end{array}$} & $\mathbf{r}$ & $0.871^{*}$ & $0.772^{*}$ & $0.813^{*}$ & $0.678^{*}$ & $0.777^{*}$ & 1 & & & \\
\hline & p & 0.000 & 0.000 & 0.000 & 0.000 & 0.000 & - & & & \\
\hline & $\mathbf{N}$ & 354 & 354 & 354 & 354 & 354 & 354 & & & \\
\hline \multirow{3}{*}{$\begin{array}{l}\text { Occupational } \\
\text { Exam }(7)\end{array}$} & $\mathbf{r}$ & $0.373^{*}$ & $0.272^{*}$ & $0.255^{*}$ & $0.310^{*}$ & $0.216^{*}$ & $0.244^{*}$ & 1 & & \\
\hline & p & 0.000 & 0.000 & 0.000 & 0.000 & 0.000 & 0.000 & - & & \\
\hline & $\mathbf{N}$ & 354 & 354 & 354 & 354 & 354 & 354 & 354 & & \\
\hline \multirow{3}{*}{ Adaptation (8) } & $\mathbf{r}$ & $0.774^{*}$ & $0.659^{*}$ & $0.746^{*}$ & 0.599* & $0.671^{*}$ & 0.690* & $0.228^{*}$ & 1 & \\
\hline & p & 0.000 & 0.000 & 0.000 & 0.000 & 0.000 & 0.000 & 0.000 & - & \\
\hline & $\mathbf{N}$ & 354 & 354 & 354 & 354 & 354 & 354 & 354 & 354 & \\
\hline
\end{tabular}

Note: * $\mathrm{p}<0.05$

According to the sample group's variable of gender, it was determined that there were significant differences between males and females in the subscales of the "Occupational Exam" Table 2. It was observed that female 
prospective teachers had higher scores compared to male prospective teachers. It is believed that male prospective physical education and sports teachers could act alone while dealing with problems and had lower levels of imagination, which enabled them to be more successful in coping with stress and feel more positive compared to female prospective teachers. Thus, it could be stated that their anxiety levels are low. In Turkey, it can be stated that several dominant impressions include that teaching is a suitable profession for females especially, it enables them to maintain both family and professional lives, and it is important to become a civil servant. This social thought could be the reason why the profession of teaching is regarded as a job that should be acquired more by prospective female teachers compared to male prospective teachers. In the review of previous studies, it was observed that female prospective teachers had higher levels of anxiety compared to male prospective teachers (Akgün \& Ozgür, 2014; Aras \& Karakaya, 2020; Cubukçu \& Dönmez, 2011; Mergen et al., 2014; Özbal \& Ektirici, 2017; Taşğın, 2006; Uğurlu, Karakaya, Coşkuner, \& Bulut, 2020). In a study conducted by Harmandar, Serdar, and Demirel (2018) according to the variable of gender, it was concluded that females had higher scores in the subscales of "Job Orientation", "Interaction with Students", and "Occupational Exam". Aycan and Üzüm (2019) reported that the levels of occupational anxiety perceived by the participants exhibited statistically significant differences in terms of the participants' variable of gender. Contrarily, Donmuş et al. (2017) determined that the occupational anxiety levels of prospective male teachers were higher compared to those of female prospective teachers. Furthermore, in the review of other studies, it was observed that several studies did not observe any difference in the subscales of occupational anxiety scale in terms of the variable of gender (Alisinanoğlu, Kesicioğlu, \& Ünal, 2010; Atmaca, 2013; Bozdam \& Taşğın, 2011; Tasdemir, 2015).

In the study, statistically significant differences were observed only in the subscale of "Adaptation" in terms of the prospective physical education and sports teachers' variable of grade level, according to $2^{\text {nd }}$-grade and $4^{\text {th }}-$ grade students Table 3. In other subscales, no statistically significant difference was observed. The reason for that could be the fact that prospective physical education and sports teachers encounter a new environment and social circle in the first years of university and start living away from their families for a time, which results in anxiety. Additionally, the fact that these years cover the final periods of the adolescence of prospective physical education and sports teachers and being $2^{\text {nd }}$-grade students could be related to their lack of occupational self-confidence. In the review of other studies, it was observed that the grade level was a significant variable. Alisinanoğlu et al. (2010) stated that the grade level was a significant factor in terms of the occupational anxiety levels of students. Cubukçu and Dönmez (2011) concluded that $1^{\text {st }}$-grade students had higher levels of anxiety compared to $2^{\text {nd }}$-grade students.

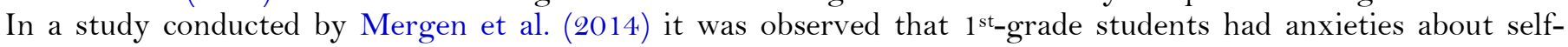
worth, duty, and effectiveness. Harmandar et al. (2018) determined that the anxiety scores of $3^{\text {rd }}$-grade students in the subscales of "Socioeconomics" and "Occupational Exam" were higher compared to the participants who studied at other grade levels. It was also emphasized that prospective teachers who receive lessons, "Classroom Management", "Special Teaching Methods", and "School Experience", at the $3^{\text {rd }}$ grade start to get involved in the practical field, which increases their occupational anxiety levels. In a study conducted by Bilgici and Deniz (2016) it was determined that the level of occupational anxiety increased in parallel with the grade level. Furthermore, several studies concluded that the anxiety levels of $1^{\text {st }}$-grade and $2^{\text {nd }}$-grade students were higher compared to $3^{\text {rd }}$-grade and $4^{\text {th-grade }}$ students (Atmaca, 2013; Dursun \& Karagün, 2012; Mergen et al., 2014). Conversely, several studies did not encounter any statistically significant difference in terms of the variable of grade level (Akgün \& Ozgür, 2014; Tasdemir, 2015; Türkdoğan, 2014).

According to the perceptions of the participants, it was determined that the "Occupational Anxiety Scale" and the subscale of "Job Orientation" were positively and very strongly correlated. Furthermore, the weakest correlation was observed between the subscales of "Occupational Exam" and "Colleagues and Parents", which was positive and very weak Table 4. According to this result, it could be stated that the prospective physical education and sports teachers had anxieties about serving in the future while this anxiety could influence their tendencies toward life. In a study conducted by Akbulut, Erol, and Say (2018) in terms of occupational anxiety levels, no significant relationship was observed between the subscales of colleague/parent- and student/communication-based anxiety and the subscales of willingness to learn, development, and openness. It was also determined that school management-based anxiety was negatively and very weakly correlated with the subscales of willingness to learn, development, and openness. Dogan and Coban (2009) determined that occupational anxiety levels were negatively and significantly correlated with attitudes toward the profession. Furthermore, several studies conducted with prospective teachers reported that the occupational anxiety levels of prospective teachers decreased as the selfefficacy levels were increased, which indicated that self-efficacy was a significant predictor of occupational anxiety (Dadandı et al., 2016; Gökmen \& Ekici, 2018; Kahraman \& Celik, 2019; Ünlü \& Erbaş, 2018).

In Turkey, the largest anxiety of prospective teachers is regarded as the failure in the occupational exam. This is because it is not enough for prospective teachers to graduate from faculties of education to start working in state schools. They are required to become successful in the occupational exam (Public Personnel Selection Exam is a selection exam that determines whether individuals with qualities of teaching will be appointed. The fact that a certain number of teachers are appointed and the benefits of being a teacher in a state school make this exam a very important one.) Accordingly, prospective teachers make efforts to work in the profession without overcoming certain obstacles while experiencing occupational anxiety. This emerges as a problem for prospective teachers who wish to conduct their profession (Aycan \& Üzüm, 2019; Bozdam, 2008; Can \& Can, 2011; Celen \& Bulut, 2015; Gökmen \& Ekici, 2018; Karakaya \& Karataş, 2017). In a study conducted by Akgün and Ozgür (2014) it was determined that the subscale that caused the highest level of anxiety in prospective teachers was occupational exam while the lowest level of anxiety was due to the subscale of colleagues and parents. Sadıkoğlu, Hastürk, and Polat (2018) reported that prospective teachers experienced anxieties about maintaining their lives while starting to work and practicing their profession of teaching. Ünaldı and Alaz (2008) stated that if the anxiety levels of prospective teachers decreased, they could use their energies more efficiently and conduct their professions more carefully.

Anxiety was observed to be a factor that could be effective in the mental and physical health of teachers, their performance in the education process, and their attitudes toward the profession. Prospective physical education and 
sports teachers should be trained in a way that enables them to experience low levels of occupational anxiety, to cope with difficulties, and to guide students in discovering themselves, developing their skills, and establishing values. Guidance services in the pre-service period can inform prospective students about the profession of teaching, teaching skills, and appointments from the $1^{\text {st }}$-grade onwards. Prospective teachers who are supported in such a way can reach higher levels of self-efficacy in addition to avoiding anxiety problems that can result in negative psychological outcomes. Moreover, investigating occupational anxiety before and after the teaching practice of prospective teachers is believed to have a quality that can contribute to the further comprehension of the subject. Based on the results of the study, the following suggestions were presented to reduce the occupational anxiety levels of prospective physical education and sports teachers.

- The occupational anxiety levels of prospective physical education and sports teachers can be reduced by introducing long-term plans and balancing the numbers of students to be admitted and teachers to be appointed by the Ministry of National Education.

- The adaptation-based anxiety levels of prospective physical education and sports teachers can be directed toward in-service training that emphasizes the importance of teaching at classroom levels and the significance of regional differences and environments while practicing the profession of teaching.

- Methods that can keep the occupational anxieties of prospective physical education and sports teachers under control can be presented within the framework of undergraduate programs.

- Encouraging prospective physical education and sports teachers to use guidance services actively can be adopted as a successful way to increase the academic achievements of prospective teachers while reducing their anxiety levels.

- The concept of occupational anxiety in prospective physical education and sports teachers can be investigated by qualitative and mixed-method studies.

\section{References}

Akbulut, S., Erol, A., \& Say, S. (2018). Examining the relationship between lifelong learning tendencies and occupational anxiety of the teacher candidates. Journal of Education and New Approaches, 1(1), 1-11.

Akgün, F., \& Ozgür, H. (2014). Examination of the anxiety levels and attitudes of the information technology pre-service teachers towards the teaching profession. Journal of Theory and Practice in Education, 1O(5), 1206-1223.

Alisinanoğlu, F., Kesicioğlu, O., \& Ünal, E. (2010). Investigation of pre-school teachers' professional anxiety levels (translation: Investigation of occupational anxiety in prospective pre-school teachers). Paper presented at the 2nd International Teacher Training Policies and Problems Symposium. Ankara: Hacettepe University.

Allinder, R. M. (1994). The relationship between efficacy and the instructional practices of special education teachers and consultants. Teacher Education and Special Education, 17(2), 86-95. Available at: https://doi.org/10.1177/088840649401700203.

Aras, E., \& Karakaya, Y. E. (2020). E-learning in sports education institutions in Turkey. Malaysian Online Journal of Educational Sciences, $8(1), 14-26$.

Atmaca, H. (2013). The professional concerns of teachers candidates who enrolled in English, French and German teaching departments. Turkish Studies, 8(10), 67-76.

Aycan, A., \& Üzüm, H. (2019). Occupational anxiety of physical education teacher candidates. Bolu Abant İzzet Baysal University Journal of Education Faculty, 19(3), 745-753. Available at: https://dx.doi.org/10.17240/aibuefd.2019.19.49440-571174.

Bilgici, B. G., \& Deniz, Ü. (2016). Investigation of occupational anxieties of preschool teacher candidates in terms of some demographic features. Cumhuriyet International Journal of Education, 5(1), 53-70. Available at: https://doi.org/10.30703/cije.321383.

Bozdam, A. (2008). Examination the occupational anxiety levels of master candidates according to some variables. Master Thesis, Selcuk University, Institute of Health Sciences, Konya.

Bozdam, A., \& Taşğın, Ö. (2011). Examination the occupational anxiety levels of master candidates according to some variables. Selçuk University Journal of Physical Education and Sport Science, 13(1), 44-53.

Cabi, E., \& Yalçınalp, S. (2013). Occupational anxiety scale for prospective teachers: A study on validity and reliability. Hacettepe University, Journal of Education, 44, 85-96.

Can, S., \& Can, G. (2011). Stress levels of students before KPSS (public personnel selection exam). Kastamonu Education Magazine, 19(3), 765778.

Capa, Y., \& Cil, N. (2000). Investigation of teacher candidates' attitudes towards teaching profession in terms of different variables (translation: Investigation of the attitudes of prospective teachers toward the profession of teaching according to different variables). Hacettepe University, Journal of Education, 18, 69-73.

Celen, A., \& Bulut, D. (2015). Assessment of occupational anxiety levels of physical education preservice teachers (AIBU example). The Journal of Academic Social Science, 3(18), 247-261.

Celik, M. (2017). The relation between the occupational anxiety level and personal characteristics of Turkish teacher candidates. Nevşehir Hacı Bektaş Veli University, Institute of Social Sciences, Department of Turkish Language and Literature, Master Thesis, Nevşehir.

Cousins, J. B., \& Walker, C. A. (2000). Predictors of educators' valuing of systemic inquiry in schools. Canadian Journal of Program Evaluation, 25, 52 .

Cubukçu, Z., \& Dönmez, A. (2011). The examination of the professional anxiety levels of teacher candidates. Theory and Practice in Education, $7(1), 3-25$.

Dadandı, İ., Kalyon, A., \& Yazıcı, H. (2016). Teacher self-efficacy beliefs, concerns and attitudes towards teaching profession of faculty of education and pedagogical formation students. Journal of Bayburt Education Faculty, 1 1 (1), 253-269.

Dogan, T., \& Coban, A. E. (2009). The investigation of the relations between students' attitude toward teaching profession and anxiety level in faculty of education. Education and Science, 34(153), 157-168.

Donmuş, V., Akpunar, B., \& Eroğlu, M. (2017). The investigation of the relationship between the academic self-efficacy and occupational anxiety of teacher candidates. Mustafa Kemal University, Journal of Social Sciences Institute, 14(37), 1-13.

Dursun, S., \& Karagün, E. (2012). Assessment of occupational anxiety levels of preservice teachers: A research on the students in their final year at the school of physical education and sports at Kocaeli university. Kocaeli University Journal of Social Sciences Institutes, 24, 93112 .

Fuller, F. F. (1996). Concerns of teachers: A developmental conceptualization. American Educational Research Journal, 6(2), $207-226$.

Gökmen, A., \& Ekici, G. (2018). Investigating the relationship between preservice biology teachers' perception level of teacher self-efficacy and their occupational anxiety. Anatolian Journal of Teacher, 2(2), 17-28.

Güven, D. (2010). Teaching as a profession: The case of Turkey. Boğaziçi University Journal of Education, 27(2), 13-21.

Harmandar, D. D., Serdar, E., \& Demirel, M. (2018). Determination of occupational anxiety levels of teacher candidates studying in different departments. International Journal of Human Sciences, 15(4), 2168-2 179. Available at: 10.14687/jhs.v15i4.5487.

Kahraman, Ü., \& Celik, K. (2019). The relationship between self-efficacy beliefs and professional concerns of the faculty of education formation students. Pamukkale University, Journal of Education, 45, 353-375. Available at: 10.9779/PUJE.2018.237.

Kalaycı, Ş. (2006). SPSS applied multivariate statistics techniques (translation: SPSS applied multivariate statistical techniques). Ankara: Asil Yayın Dağıtım. 
Karakaya, Y. E., \& Karataş, B. (2017). The current state and needs of postgraduate education in sport sciences. Kastamonu Education Journal, 25(4), 1469-1482.

Mergen, H., Arslan, H., Mergen, B. E., \& Arslan, E. (2014). Pre-service teachers' anxiety and attitudes toward their profession. NWSAEducation Sciences, 9(2), 162-177. Available at: http://dx.doi.org/10.12739/NWSA.2014.9.2.1C0612.

Mishra, S. K., \& Yadav, B. (2013). Job anxiety and personality adjustment of secondary school teachers in relation of gender and types of teacher. Educational Research International, 1(1), 105-126.

Özbal, A., \& Ektirici, A. (2017). Examining occupational anxiety levels of physical education and sports teacher department students. Journal Sportive Sight: Journal of Sport and Education, 1(1), 46-55.

Sadıkoğlu, M., Hastürk, G., \& Polat, O. (2018). Examination of science prospective teachers' occupational anxiety levels. The Journal of International Social Research, 11 (56), 629-637. Available at: http://dx.doi.org/10.17719/jisr.20185639035.

Singh, S. (201 1). Level of anxiety among prospective teachers. Shaikshik Parisamuad International Journal of Education, 7(7), 17-2 1.

Tabachnick, B. G., Fidell, L. S., \& Ullman, J. B. (2007). Using multivariate statistics (Vol. 5, pp. 481-498). Boston, MA: Pearson.

Tasdemir, C. (2015). Examining occupational anxiety level of Mathematics teachers for some variables. Educational Research and Reviews, $10(12), 1578-1585$.

Taşğın, O. (2006). Observation of concern levels teacher candidates, who enrolled physical education and sports college, according to some variables. Kastamonu Education Journal, 14(2), 679-686.

Tektaş, N. (2014). Inspecting the anxiety levels of graduates. Selcuk University Journal of Institute of Social Sciences, $243-253$.

Türkdoğan, S. C. (2014). Professional concerns of preservice teachers according to their reason for choosing teaching profession. Master Thesis, Pamukkale University Institute of Educational Sciences, Denizli.

Uğurlu, F. M., Karakaya, Y. E., Coşkuner, Z., \& Bulut, Ö. F. (2020). Examination of physical education and sports teacher candidates' anxiety about the profession according to various variables. Paper presented at the 3rd International Congress of Physical Education, Sport, Recreation and Dance, Istanbul, Turkey.

Ünald,, Ü., \& Alaz, A. (2008). Investigation of transports of some carboxylic acids through a polisulfone anion exchange membrane. Selcuk University Ahmet Keleşoğlu Education Faculty Journal, 26, 1-13.

Ünlü, H., \& Erbaş, M. K. (2018). Academic self-efficacy and occupational anxiety of physical education teacher candidates. Turkish Journal of Sports Science, 2(1), 15-25. 